\title{
Essential Key Points for Zinc Biofortification - Uptake, Translocation and Accumulation in Higher Plants
}

\author{
Fernando José Cebola Lidon ${ }^{1 *}$, José Cochicho Ramalho², António Eduardo Leitão², Maria Fernanda Guedes \\ Pinto $^{1}$, Maria Manuela Abreu da Silva ${ }^{3}$ and Fernando Henrique Reboredo ${ }^{1}$ \\ ${ }^{1}$ Faculdade de Ciências e Tecnologia, Universidade Nova de Lisboa, Portugal
}

${ }^{2}$ Instituto Superior de Agronomia (ISA), Universidade de Lisboa (ULisboa), Portugal

${ }^{3}$ ESE Almeida Garrett, Largo do Sequeira, Portugal

Submission: January 27, 2017; Published: March 09, 2017

"Corresponding author: Fernando José Cebola Lidon, DCT, Faculdade de Ciências e Tecnologia, Universidade Nova de Lisboa, Quinta da Torre, Campus da Caparica, 2829-514 Caparica, Portugal, Email: fjl@fct.unl.pt

\begin{abstract}
Owing to continuous development of knowledge, to understand the mechanisms underlying the bio fortification with $\mathrm{Zn}$ in plants, a synoptical overview of this metal uptake, translocation and accumulation in plant organs are assessed. In this context, the mechanisms of bio fortification of plants with zinc are additionally correlated with soil interacting factors, namely $\mathrm{pH}$ and moisture.
\end{abstract}

Keywords: Zn bio fortification; Zn accumulation; Zn deposition within organs; Zn translocation; Zn uptake

\section{Zinc Accumulation}

The amounts of $\mathrm{Zn}$ in unpolluted soils typically are below $125 \mathrm{ppm}$ [1-3] with the bioavailability of this metal in soil solution increasing at low $\mathrm{pH}$ and the organic ligands and hardness cations such as $\mathrm{Ca}^{2+}$ decreasing its availability [4]. In this context, plant species differ in both their $\mathrm{Zn}$ requirements and tolerance $[5,6]$. Most plants require leaf $\mathrm{Zn}$ concentrations greater than $0.02-0.04 \mathrm{mg} \mathrm{g-1} 1_{\mathrm{dw}}$, whereas their growth is inhibited at leaf $\mathrm{Zn}$ concentrations greater than 0.1-0.77 mg g- $1_{d w}[6-8]$.

The threshold of toxicity is mostly determined by environmental pollution following industrial and agricultural activities, such as smelter and incinerator emissions, dispersal from mine wastes, excessive applications of $\mathrm{Zn}$-containing fertilizers or pesticides and use of Zn-contaminated sewage sludges, manures or industrial wastes as fertilizers [4,9]. Nevertheless, in this case about $15-20$ species (mostly belonging to the Brassicaceae) can hyper accumulate about $3000 \mathrm{mg} \mathrm{Zn}$ $\mathrm{kg}-1_{\mathrm{dw}}[5,10-13]$, since can tolerate more $\mathrm{Zn}$ in their tissues and even require greater leaf $\mathrm{Zn}$ concentrations for optimal growth $[5,13,14]$.

In the roots, $\mathrm{Zn}$ prevails in the elongation zone, being concentrated in endo dermal cells of dicotyledonous species and in the pericycle of monocotyledonous species [15]. In Zn-hyper accumulator plants more than $30 \%$ of this metal is usually associated with cell walls, and much of the remainder is complexed with histidine $[16,17]$.

$\mathrm{Zn}$ accumulation within shoots, although varying between plant species, accumulates in the leaf epidermal cells, with the exception of guard cells, particularly in older leaves [15,18-22], and trichomes [22-24]. In Zn-hyperaccumulator plants, 20-50\% of $\mathrm{Zn}^{2+}$ is chelated with vacuolar carboxylic acids, such as citrate, malate, and oxalate, whereas up to $45 \%$ can also be associated with histidine, and the remainder is largely bound to phosphategroups and cell-wall components $[16,17,20,25,26]$. In the cereal grains, $\mathrm{Zn}$ accumulates in the aleurone and scutellum of the embryo, and, at a lower level in the endosperm [27-39].

\section{Zinc Uptake and Translocation}

Metals availability for plant uptake is driven by complex interactions between the chemical properties of cations, the composition and physicochemical properties of the soil, microbial activity and plant roots [40]. In this context, Zn uptake, although depending of the composition in the growth media, follows a 
linear pattern with its concentration in the nutrient solution or in the soils [41-43], occurring its mobilization to the roots xylem through the symplast and apoplast in regions of the root lacking a Casparian Band, to the stele where it enters the xylem $[5,8]$. Nevertheless, inconsistent studies about kinetics uptake of $\mathrm{Zn}$ report the occurrence of active and passive mechanism [44-47], although being recognized that its mobility in the xylem fluids is highly due to its bind to light organic compounds [48].

Transport of bio available $\mathrm{Zn}^{2+}$ across the plasma membrane is the initial step of the uptake and accumulation kinetics, but cellular transition metal uptake systems seem to operate as uni porters or secondary carriers driven by protons, further implicating channel proteins. Some channels might let the passage of ions based solely on their positive or negative charge, whereas groupings of ion channels regulate the passage through the pore and can open or close by chemical or electrical signals and temperature. Additionally, non selective cation channels further have the capacity to catalyze passive fluxes of cations, namely $\mathrm{Zn}^{2+}$, through plant membranes [49]. Long-distance transport of $\mathrm{Zn}$ to the shoot, involves symplastic diffusion between interconnected root cells towards the stele and active loading across the plasma membrane of the xylem parenchyma into the apoplastic xylem [50]. Paralleling this xylem loading, the translocation rate of $\mathrm{Zn}$ from roots further depends of $\mathrm{Zn}$ accessibility and mobilization from vacuoles of the roots and a subsequent passage across the endodermis, where nicotinamine acts as a Zn ligand [51]. Within xylem sap, long-distance transport further implicates chelation by mobile low-molecularweight ligands present in the xylem sap [52-54]. $\mathrm{Zn}^{2+}$ destined for the developing seed leave the xylem, follows an active loading kinetics into the phloem $[55,56]$ and, therefore, this metal ions are likely to form complexes with YSL proteins transport metalnicotinamine complexes [57]. Through symplastic efflux from the phloem and plasma membrane influx $\mathrm{Zn}$ reaches the embryo and the endosperm of the seed [55].

\section{Bio Fortification with Zinc}

The bio fortification of plants with $\mathrm{Zn}$ is dependent on the size of plant-available $\mathrm{Zn}$ pools in soil. Additionally, transport of $\mathrm{Zn}$ to root surface in soils occurs predominantly via diffusion [58], being this process is highly sensitive to soil $\mathrm{pH}$ and moisture. Among the soil chemical factors, soil $\mathrm{pH}$ plays the most important role in $\mathrm{Zn}$ solubility in soil solution. In a $\mathrm{pH}$ range between 5.5 and 7.0, $\mathrm{Zn}$ concentration in soil solution is decreased by 30 to 45 -fold for each unit increase in soil $\mathrm{pH}$, thus increasing a risk for development of $\mathrm{Zn}$ deficiency in plants [59]. Increasing soil $\mathrm{pH}$ stimulates adsorption of $\mathrm{Zn}$ to soil constituents and reduces the desorption of the adsorbed $\mathrm{Zn}$. At pH 5.0 the concentration of $\mathrm{Zn}^{2+}$ in soil solution is sufficiently high, about $6.5 \mathrm{mg} \mathrm{kg}^{-1}$. When soil $\mathrm{pH}$ increased from 5 to 8 , concentration of soil solution $\mathrm{Zn}^{2+}$ is reduced 1,000 times and becomes approx. $0.007 \mathrm{mg} \mathrm{kg}^{-1}$. Thus, an increase in soil $\mathrm{pH}$ is associated with strong decreases in the concentrations of $\mathrm{Zn}$ in plant tissues [60,61].
The role of soil moisture is very critical for an adequate $\mathrm{Zn}$ diffusion to plant roots in soils with low $\mathrm{Zn}$ availability $[61,62]$, whereas the soil organic matter plays a critical role in solubility and transport of $\mathrm{Zn}$ to plant roots [61,63-65]. Accordingly, the pool of readily available $\mathrm{Zn}$ to plant roots may be extremely low in soils with high $\mathrm{pH}$ and reduced levels of organic matter and soil moisture.

\section{References}

1. Ebbs SD, Kochian LV (1997) Toxicity of zinc and copper to Brassica species: implications for phytoremediation. J Environ Quality 26(3): 776-781.

2. Di Baccio D, Tognetti R, Sebastiani L, Vitagliano C (2003) Responses of Populus deltoides $\mathrm{x}$ Populus nigra (Populus $\mathrm{x}$ euramericana) clone I-214 to high zinc concentrations. New Phytol 159(2): 443-452.

3. Hussain S, Maqsood MA, Rahmatullah (2010) Increasing grain zinc and yield of wheat for the developing world: A Review. Emir J Food Agric 22(5): 326-339.

4. Pedler JFTB, Kinraide D, Parker R (2004) Zinc rhizo toxicity in wheat and radish is alleviated by micro molar levels of magnesium and potassium in solution culture. Plant Soil 259(1-2): 191-199.

5. Broadley MRP, White J, Hammond J P, Zelko I, Lux A (2007) Zinc in plants. New Phytol 173: 677-702.

6. Fageria NK (2009) The Use of Nutrients in Crop Plants. Boca Raton, CRC Press, USA, pp. 448.

7. Bowen HJM (1979) Environmental chemistry of the elements. Academic Press, New York, USA.

8. White PJ, Brown PH (2010) Plant nutrition for sustainable development and global health. Ann Bot 105(7): 1073-1080.

9. Giuffré L, Romaniuk RI, Marbán L, Ríos RP, García Torres TP (2012) Public health and heavy metals in urban and peri urban horticulture. Emir J Food Agric 24(2): 148-154.

10. Reeves RD, Baker AJM (2000) Metal-accumulating plants. In: Phyto remediation of Toxic Metals: Using Plants to Clean Up the Environment. Raskinand I and Ensley ED (Eds.), John Wiley \& Sons, New York, USA, pp. 193-229.

11. Verbruggen N, Hermans C, Schat H (2009) Molecular mechanisms of metal hyper accumulation in plants. New Phytol 181(4): 759-776.

12. Krämer U (2010) Metal hyper accumulation in plants. Annu Rev Plant Biol 61: 517-534.

13. White PJ (2012) Long-distance transport in the xylem and phloem. In: Marschner P (Ed.), Marschner's Mineral Nutrition of Higher Plants. (3 ${ }^{\text {rd }}$ edn), Academic Press, London, England, UK, p. 49-70.

14. Hammond JP, Bowen HC, White PJ, Mills V, Pyke KA, et al. (2006) A comparison of the Thlaspi caerulescens and Thlaspi arvense shoot transcriptomes. New Phytol 170(2): 239-260.

15. Vázquez MD, Poschenrieder C, Barceló J, Baker AJM, Hatton P, et al. (1994) Compartmentation of zinc in roots and leaves of the zinc hyper accumulator Thlaspi caerulescens. J \& C Presl Bot Acta 107(4): 243-250.

16. Salt DE, Prince RC, Baker AJM, Raskin I, Pickering IJ (1999) Zinc ligands in the metal hyperaccumulator Thlaspi caerulescens as determined using X-ray absorption spectroscopy. Environ Sci Technol 33(5): 713717.

17. Monsant AC, Kappen P, Wang Y, Pigram PJ, Baker AJM, et al. (2011) In vivo speciation of zinc in Noccaea caerulescens in response to nitrogen form and zinc exposure. Plant Soil 348: 167-183. 
18. Küpper H, Zhao FJ, McGrath SP (1999) Cellular compartmentation of zinc in leaves of the hyper-accumulator Thlaspi caerulescens. Plant Physiol 119(1): 305-311.

19. Frey B, Keller C, Zierold K, Schulin R (2000) Distribution of Zn in functionally different leaf epidermal cells of the hyper accumulator Thlaspi caerulescens. Plant Cell Environ 23(7): 675-687.

20. Küpper H, Mijovilovich A, Meyer-Klaucke W, Kroneck PMH (2004) Tissue and age-dependent differences in the complexation of cadmium and zinc in the cadmium/zinc hyper accumulator Thlaspi caerulescens (Ganges eco-type) revealed by X-ray absorption spectroscopy. Plant Physiol 134(2): 748-757.

21. Ma J F, Ueno D, Zhao FJ, McGrath SP (2005) Sub cellular localisation of $\mathrm{Cd}$ and $\mathrm{Zn}$ in the leaves of a Cd-hyper accumulating ecotype of Thlaspi caerulescens. Planta 220: 731-736.

22. Monsant AC, Wang Y, Tang C (2010) Nitrate nutrition enhances zinc hyper accumulation in Noccaea caerulescens (Prayon). Plant Soil 336(1): 391-404.

23. Küpper H, Lombi E, Zhao FJ, McGrath SP (2000) Cellular compartmentation of cadmium and zinc in relation to the elements in the hyper accumulator Arabidopsis halleri. Planta 212: 75-84.

24. Zhao F J, Lombi E, Breedon T, McGrath SP (2000) Zinc hyper accumulation and cellular distribution in Arabidopsis halleri. Plant Cell Environ 23(5): 507-514.

25. Tappero R, Peltier E, Gräfe M, Heidel K, Ginder-Vogel M, et al. (2007) Hyper accumulator Alyssum murale relies on a different metal storage mechanism for cobalt than for nickel. New Phytol 175(4): 631-634.

26. Sarret G, Willems G, Isaure MP, Marcus MA, Fakra SC, et al. (2009) Zinc distribution and speciation in Arabidopsis halleri×Arabidopsis lyrata progenies presenting various zinc accumulation capacities. New Phytol 184(3): 581-595.

27. Mazzolini AP, Pallaghy CK, Ledgge GJF (1985) Quantitative microanalysis of Mn, $\mathrm{Zn}$ and other elements in mature wheat seed. New Phytol 100(4): 483-509.

28. Lin L, Ockenden I, Lott JNA (2005) The concentrations and distribution of phytic acid-phosphorus and other mineral nutrients in wild-type and low phytic acid1-1 (lpa1-1) corn (Zea mays L.) grains and grain parts. Can J Bot 83(1): 131-141.

29. Ozturk L, Yazici MA, Yucel C, Torun A, Cekic C, et al. (2006) Concentration and localization of zinc during seed development and germination in wheat. Physiol Plant 128: 144-152.

30. Liu K, Peterson KL, Raboy V (2007) Comparison of the phosphorus and mineral concentrations in branandabraded kernel fractions of a normal barley (Hordeum vulgare) cultivar versus four low phytic acid isolines. J Agric Food Chem 55(11): 4453-4460.

31. Cakmak I (2008) Enrichment of cereal grains with zinc: agronomic or genetic biofortification?. Plant Soil 302(1): 1-17.

32. Hansen TH, Laursen KH, Persson DP, Pedas P, Husted S, et al. (2009) Micro-scaled high-through put digestion of plant tissue samples formulti elemental analysis. Plant Methods 5: 12 .

33. Persson DP, HansenTH, Laursen KH, Schjoerring JK, Husted S (2009) Simultaneous iron, zinc, sulfur and phosphorus speciation analysis of barley grain tissues using SEC-ICP-MS and IP-ICP-MS. Metallomics 1: 418-426.

34. Cakmak I, Kalayci M, Kaya Y, Torun AA, Aydin N, et al. (2010) Bio fortification and localization of zinc in wheat grain. J Agric Food Chem 58(16): 9092-9102.

35. Cakmak I, Pfeiffer WH, McClafferty B (2010) Bio fortification of durum wheat with zinc and iron. Cereal Chem. 87: 10-20.
36. Lombi E, Smith E, HansenTH, Paterson D, de Jonge MD, et al. (2011) Megapixel imaging of (micro) nutrients in mature barley grains. J Exp Bot 62(1): 273-282.

37. Stomph TJ, Choi EY, Stangoulis JCR (2011) Temporal dynamics in wheat grain zinc distribution: is sink limitation the key? Ann Bot 107(6): 927937.

38. Lidon FC, Almeida AS, Costa AR, Bagulho AS, Scotti-Campso P, et al. (2015) Sequential $\mathrm{Zn}$ and Fe bio fortification of bread wheat grains - From controlled to uncontrolled environments. Crop and Pasture Science 66(11): 1097-1104.

39. Pataco IM, Lidon FC, Ramos I, Oliveira K, Guerra M, et al. (2017) Bio fortification of durum wheat (Triticum turgidum L. ssp. durum (Desf.) Husnot) grains with nutrients. J Plant Interactions 12: 39-50.

40. Antunes PM, Berkelaar EJ, Boyle D, Hale BA, Hendershot W, et al. (2006) The biotic ligand model for plants and metals: technical challenges for field application. Environ Toxicol Chem 25(3): 875-882.

41. Thoresby P, ThorntonI (1979) Heavy metals and arsenic in soil, pasture herbage and barley in some mineralised areas in Britain. In: Hemphill DD (Ed.), Trace Subst Environ. Health, University of Missouri, Columbia, USA, p. 13.

42. Kabata Pendias A, Pendias H (2001) Trace elements in soils and plants. CRC Press, Boca Raton, London, New York, Washington, USA.

43. Tsonev T, Lidon FJC (2012) Zinc in plants - An overview. Emirates Journal of Food and Agriculture 24(4): 322-333.

44. Schmidt WE, Hagg HP, Epstein E (1965) Absorption of zinc by excised barley roots. Physiol Plant 18(3): 860-869.

45. Bowen JE (1969) Absorption of copper, zinc and manganese by sugarcane leaf tissue. Plant Physiol 44: 255-261.

46. Kochian LV (1993) Zinc absorption from hydroponic solution by plant roots. In: A. D.Robson (Ed.), Zinc in Soils and Plants. Kluwer Academic Publishers. Dordrecht pp. 45-57.

47. Brennan RF (2005) Zinc Application and Its Availability to Plants. PhD dissertation, School of Environmental Science, Division of Science and Engineering, Murdoch University, Australia.

48. Tiffin LO (1977) The form and distribution of metals in plants: an overview. In: Proc. Hanford Life Sciences Symp. U.S. Department of Energy, Symposium Series, Washington, USA, pp. 315.

49. Demidchik V, Davenport RJ, Tester M (2002) Nonselective cation channels in plants. Annu Rev Plant Biol 53: 67-107.

50. Sondergaard TE, Schulz A, Palmgren MG (2001) Energization of transport processes in plants. Roles of the plasma membraneH ${ }^{+}$ATPase. Plant Physiol 136: 2475-2482.

51. Takahashi M, Terada Y, Nakai I, Nakanishi H (2003) Role of nicotianamine in the intracellular delivery of metals and plant reproductive development. Plant Cell 15(6): 1263-1280.

52. Krämer U, Clemens S (2006) Functions and homeostasis of zinc, copper, and nickel in plants, molecule. In Molecular Biology of Metal Homeostasis and Detoxification. In: Tamas MJ, Martinoia E (Eds.) 14: 216-271.

53. Van Belleghem F, Cuypers A, Semane B, Smeets K, Vangronsveld J, et al. (2007) Subcellular localization of cadmium in roots and leaves of Arabidopsis thaliana. New Phytol 173(3): 495-508.

54. Krämer U, JanetD, Cotter-Howells I, John M, Charnock I, et al. (1996) Free histidine as a metal chelator in plants that accumulate nickel. Nature 379: 635-638.

55. Patrick JW, Offler CE (2001) Compartmentation of transport and transfer events in developing seeds. J Exp Bot 52(356): 551-564. 
56. Koike S, Inoue H, Mizuno D, Takahashi M, Nakanishi H, et al. (2004) OsYSL2 is a rice metal-nicotianamine transporter that is regulated by iron and expressed in the phloem. Plant J 39(3): 415-424.

57. Waters BM, Grusak MA (2008) Whole-plant mineral partitioning throughout the life cycle in Arabidopsis thaliana ecotypes Columbia, Landsberg erecta, Cape Verde Islands, and the mutant line ysl1ysl3. New Phytol 177(2): 389-405.

58. Wilkinson HF, Loneragan JF, Quick JP (1968) The movement of zinc to plant roots. Soil Sci Soc Amer Proc 32: 831-833.

59. Marschner H (1993) Zinc uptake from soils. In: Robson AD (ed) Zinc in Soils and Plants. Kluwer, Dordrecht, The Netherlands, p. 59-77.

60. Sarkar AN, Wynjones RG (1982) Effect of rhizosphere pH on the availability and uptake of Fe, Mn and Zn. Plant Soil 66(3): 361-372.

61. Marschner H (1995) Mineral nutrition of higher plants. (2 ${ }^{\text {nd }}$ edn), Academic Press, London, UK.
62. Rattan RK, Deb DL (1981) Self-diffusion of zinc and iron in soils as affected by $\mathrm{pH}, \mathrm{CaCO}_{3}$, moisture, carrier and phosphorus levels. Plant Soil 63(3): 377-393.

63. Obrador A, Novillo J, Alvarez JM (2003) Mobility and availability to plants of two zinc sources applied to a calcareous soil. Soil Sci Soc Am J $67(2): 564-572$

64. Kirk B, Coles J, Horst wood MSA (2004) Isotopic discrimination of zinc in higher plants. New Phytol 165(3): 703-710.

65. Zhu J, Raschke K, Köhler B (2007) An electro genic pump in the xylem parenchyma of barley roots. Physiol Plant 129(2): 397-406.

66. Defago GC (1995) Pseudomonad as bio control agents of diseases caused by soil-borne pathogens. In: Hokkanen HMT, JM Lynch (Eds.), Benefits and Risks of Introducing Biocontrol Agents. Cambridge University Press, England, UK, pp. 137-148.

\section{Your next submission with Juniper Publishers will reach you the below assets}

- Quality Editorial service

- Swift Peer Review

- Reprints availability

- E-prints Service

- Manuscript Podcast for convenient understanding

- Global attainment for your research

- Manuscript accessibility in different formats

( Pdf, E-pub, Full Text, Audio)

- Unceasing customer service

Track the below URL for one-step submission https://juniperpublishers.com/online-submission.php 